\title{
REVIEW
}

\section{Microbial life in sedimentary biofilms - the challenge to microbial ecologists}

\author{
Lutz-Arend Meyer-Reil
}

Institut für Ökologie der Ernst-Moritz-Arndt-Universität Greif́swald, Schwedenhagen 6, D-18565 Kloster/Hiddensee, Germany

\begin{abstract}
Modification and decomposition processes of material in sediments are dominated by microorganisms. Through microbial colonization, cells become immobilized at particle surfaces and embedded in an organic matrix of extracellular polysaccharides. The development of complex sedimentary biofilms is the net result of transport and exchange processes between the biofilm and surrounding water, and modification and transformation processes of matter within the biofilm. This article illustrates aspects of microbial life in sedimentary biofilms: microbial colonization of particles, key functions of extracellular polysaccharides, spatial heterogeneity of microbial distribution and activity, and distribution and availability of organic carbon. Examination of our present knowledge indicates that micro-scale measurements rather than investigations in the bulk sediment are required, that much more attention has to be paid to the fact that microorganisms condition specific features of their environment rather than simply reacting to the environment, and that availability instead of concentration of carbon has to be measured. To obtain a better insight into the function of sedimentary biofilms, traditional approaches have to be modified.
\end{abstract}

KEY WORDS: Sedimentary biofilm - Spatial heterogeneity · Micro-scale investigation · Particle colonization - Microbial distribution - Extracellular polysaccharides - Available organic carbon

\section{CHARACTERISTICS OF MICROBIAL DISTRIBUTION AND ACTIVITIES}

Modification and decomposition processes in sediments are dominated by microorganisms which may be characterized as the driving force for the cycle of elements. The dominating role of microorganisms in the diagenesis of organic matter is underlined by the following characteristics of microbial distribution and activity:

(1) Microorganisms colonize sediments in high numbers. Their biomass is comparable to the biomass of all other benthic organisms. Based on their surface area, however, microbes exceed all other organisms by far.

(2) The overwhelming portion of microorganisms in sediments are attached to particles. The immobilization of microbes on particle surfaces (formation of biofilms) is of essential importance for the understanding of microbial life in sediments.
(3) Because of the colonization of particles, microorganisms are heterogeneously distributed in space. From their micro-scale heterogeneity pronounced gradients in biological and chemical parameters arise.

(4) The microbial population in sediments comprises a broad spectrum of different physiological groups of organisms. The corresponding ecological situation, however, determines which of the physiological groups will be active.

(5) Microorganisms possess a variety of catabolic enzymes which allow them to decompose various dissolved and (by extracellular enzymes) particulate substrates. Microbes can use substrates more efficiently and can multiply more rapidly than other organisms. Instead of oxygen, alternative electron acceptors can be used under anaerobic conditions.

(6) Microorganisms readily form complex associations with each other and with higher organisms producing degradation capabilities much more powerful 
than those of a single organism (Deming \& Baross 1993).

In the following I will highlight different aspects of microbial life in sedimentary biofilms: the colonization of particles, the resulting micro-scale heterogeneity of microbial distribution and activity, and the distribution and availability of organic carbon. From discussing our present knowledge, it becomes obvious that microorganisms condition specific features of their environment rather than simply responding to the environment, that microorganisms require the study of microenvironments rather than investigations of the bulk sediment, and that availability instead of concentration of organic carbon has to be measured. The aim of this study is to stimulate studies at the corresponding spatial scale which will not only enhance our knowledge of microbial life in sedimentary biofilms, but also provide a unique insight into the function of natural microbial communities.

\section{MICROBIAL COLONIZATION OF PARTICLES}

Since most of the information was gained for pure cultures colonizing artificial surfaces in the laboratory (cf. comprehensive perspectives by Characklis \& Wilderer 1989, Characklis \& Marshall 1990, Flemming \& Geesey 1991, and literature cited therein), the present knowledge of colonization of particles by heterogeneous microbial population in natural sediments is very limited. Most of the data available relate to microbial numbers determined after homogenization/sonication, a procedure by which the fine structure of the sediment and the relation of the individual cells within the microbial assemblages are destroyed.

The microbial colonization of surfaces follows a basic pattern almost independent of type of surface and location. Four phases can be distinguished which change from purely physical to predominantly biological processes overlapping in their time sequence: biochemical conditioning, bacterial attachment, colonization with unicellular, and finally multicellular eukaryotes. The formation of a conditioning film consisting of organic macromolecules (proteins, glycoproteins, polysaccharides, humic acids) is required for bacterial attachment. Conditioning films instantaneously form when 'clean' surfaces come in contact with water. Within a few hours bacterial colonization occurs which may comprise reversible adsorption followed by nonreversible adhesion. In a third and fourth phase of colonization, unicellular (diatoms, yeasts, protozoa) and finally multicellular eukaryotes (planktonic larvae, algal spores) attach. These phases usually comprise a time frame of weeks to months (cf. Wahl 1989, and literature cited therein).
Transport of microorganisms to surfaces and subsequent attachment are governed mainly by physical forces. In the water phase microbes are transported by gravity, currents, turbulence, Brownian motion, and motility. Microturbulence, Brownian motion, diffusion, and motility are the dominating forces for transportation within the viscous layer (a physically well-structured water film which covers solid surfaces in water). At a certain distance from the surface cells are immobilized by antagonistic forces of electrical repulsion and Van-der-Waal attraction. Bacteria may bridge the electrostatic barrier by the production of polysaccharide fibrils and may be pulled towards the surface through enzymatic contraction of the fibrils: reversible adsorption is turned into nonreversible adhesion (cf. Wahl 1989, and literature cited therein). Once attached to surfaces, bacteria start to divide. Within a short period of time, heterogeneous assemblages of organisms (biofilms) originate which - together with the spectrum of particles - cause the complex structure of natural sediments.

From the few investigations of natural sediments, it becomes obvious that sand and silt particles are preferentially colonized. Obviously because of their small size, clay particles are very rarely colonized (Weise \& Rheinheimer 1978, DeFlaun \& Mayer 1983). Besides type and size of particles, the degree of roundness plays an important role in microbial colonization. As roundness (and age) of particles increase, microbial colonization decreases.

Surprisingly enough, microorganisms colonize only a small portion of the available particle surface. The values reported in the literature concerning colonization vary between 0.01 and $5 \%$ depending upon the method used for the determination of particle surfaces. In most of the investigations particle surface areas were extrapolated from grain size. Because of the high porosity of sediments, the surface areas extrapolated are too low resulting in too high densities of colonization (e.g. Dale 1974, Rublee \& Dornseif 1978). By adsorption of nitrogen onto sediments that had their organic coatings removed (DeFlaun \& Mayer 1983), the actual particle surface can be measured. However, not all of the surfaces are available for microbial colonization, resulting in too low densities of colonization. Furthermore, the direct comparison of data published in the literature concerning bacterial colonization in sediments is made more difficult by different homogenization and staining techniques that have been applied (Dale 1974, Rublee \& Dornseif 1978, Meyer-Reil 1993, and literature cited therein).

The microbial colonization of particles is characterized by a succession of different physiological groups of organisms from which bacteria adapted to higher 
nutrient concentrations seem to be the initial colonizers. It is assumed that the growth of these organisms leads to a rapid utilization of nutrients accumulated at interfaces. Only then can bacteria adapted to lower nutrient concentrations settle. This means that the former group of bacteria may have a competitive advantage over the latter group in the initial colonization of nutrient-rich surfaces, an advantage which is probably less at latter stages of successional sequence (Fletcher \& Marshall 1982). As colonization inceases, the ratio of muramic acid to ATP decreases, an indication that, following the initial colonization by prokaryotes, eukaryotes progressively settle (Morrison et al. 1977).

In preliminary investigations it could be shown that cellulose particles added to sediments were colonized within a few hours by natural microbial assemblages, although the cell density per particle remained low. The colonization was by short rods with a similar morphology. The rate of colonization and the density of cells on cellulose particles were greatly influenced by the availability of nutrients. After addition of nutrients to the interstitial water, the percentage of cellulose particles colonized as well as the average bacterial density per particle decreased. As incubation time increased, the cellulose particles decreased in size and aggregated with native particles in the sediment. These preliminary investigations are adequate to imply that complex relationships exist between cells attached to particles and those free floating in the pore water. The nutrient content of the pore water is clearly one of the factors governing this relationship; details of the dynamics of the processes, however, remain unknown (MeyerReil 1993).

Microorganisms preferentially colonize areas of low relief (crevices, depressions, surface fissures) on particles, where the cells are protected against mechanical damage (Meadows \& Anderson 1966, Weise \& Rheinheimer 1978). Investigations by DeFlaun \& Mayer (1983) revealed that habitation in protected areas is an expression of preferential survival rather than preferential colonization. The pattern of microbial colonization becomes especially obvious from scanning electron microscope photographs of the microtopography of particles. The impressive photographs taken by Weise \& Rheinheimer (1978) show that various microenvironments exist on the surface of particles thus causing the complex nature of sediments. The microbial flora quickly reaches a high degree of complexity with regard to cell sizes and modes of attachment. Single cells and aggregates of up to 20 cells are prevalent. Microcolonies consist of mixed populations right from early stages with fewer than 50 cells (Manz et al. 1993).

\section{KEY FUNCTIONS OF EXTRACELLULAR POLYSACCHARIDES (EPS)}

Attachment of microorganisms to solid surfaces stimulates the synthesis of extracellular polysaccharides (EPS) (Vandevivere \& Kirchman 1993). With increasing microbial attachment and subsequent growth, complex biofilms are formed consisting of accumulations of microorganisms immobilized at surfaces and embedded in an organic matrix of a network of microbial EPS. The development of biofilms is the net result of transport and exchange processes between the biofilm and the surrounding medium, and modification and decomposition processes of anorganic and organic matter within the biofilm. Throughout the matrix an intensive network of channels was observed that may serve for transport of gases and nutrients (Robinson et al. 1984).

EPS have key functions for the microbial cells and their surroundings (cf. review by Decho 1990). Through EPS organisms are anchored to the surface and to each other. EPS serve as protection against rapid changes in environmental parameters such as $\mathrm{pH}$, salinity, desiccation or nutrient regimes (Boyle \& Reade 1983). Furthermore EPS contribute to the resistance of cells against pollutants. Cells embedded in EPS are less sensitive to heavy metals than free-living cells. The organic matrix functions as an excellent type of communication medium for the microorganisms. It guarantees a close relation of different physiological groups of microbes which depend upon each other regarding their metabolism (e.g. nitrifying bacteria). Through the activity of immobilized microbes, pronounced gradients of inorganic and organic compounds are maintained. Along these gradients substrates can be efficiently used, and energy is conserved.

In the initial degradation of higher molecular weight material, those extracellular enzymes are important which hydrolyze large macromolecules into smaller subunits that can be metabolized by the cells (MeyerReil 1990, 1991). EPS may play a key role in retaining the activity of extracellular enzymes within a localized area close to the cells where the products of enzymatic reactions can be efficiently taken up. Due to the close relation of cells to each other, the organic matrix greatly facilitates the genetic transfer between the organisms (cf. working reports in Characklis \& Wilderer 1989). EPS exhibit a high stability (Shaw et al. 1985) and contribute significantly to the adsorption of organic and inorganic matter (e.g. Geesey et al. 1988, Ferris et al. 1989). As the age of the organic matrix increases, the deposition of minerals increases, partly caused by the activities of autotrophic bacteria (Harvey et al. 1984, Konhauser et al. 1994). 
Besides the microbes themselves, their organic matrix may represent an important food source for higher organisms in sediments (Cammen 1980, Moriarty \& Hayward 1982, Mayer 1989, Bernhard \& Bowser 1992). Up to now, carbon budgets in sediments have mainly relied on the biomass of microbial cells; the organic matrix, however, may account for large unknown portions of microbial production. Finally, through EPS particles are glued together resulting in sediment binding and stabilization.

Through secretion of the organic matrix consisting of EPS, microorganisms condition specific features of their environment rather than simply responding to variations in their environment. The cells create the specific microhabitats which allow them to metabolize and reproduce in close relation to related physiological groups of organisms while the whole community is buffered against rapid changes in environmental conditions (cf. review by Decho 1990). Traditional measurements in the bulk phase of the sediments, however, overlook the specificity of the microenvironments characteristic for microorganisms. Microbial biofilms (mats) are among the oldest witnesses to life on earth (Ehrlich 1990). The formation of biofilms can be regarded as an early step in evolution towards organizing cells in order to produce metabolic capacities which are much more powerful than those of singlecelled organisms.

\section{SPATIAL HETEROGENEITY OF MICROBIAL ACTIVITIES}

From the micro-scale distribution of microorganisms in sedimentary biofilms, pronounced gradients in microbial activities exist, although biological and chemical techniques adequate to investigate the sediment environment at the corresponding spatial scale are lacking (Watling 1988). Using a relatively coarse resolution in space, investigations have demonstrated that microbial activities are concentrated at boundary layers such as the sediment/water interface, the redox discontinuity layer or biogenic structures such as burrows and tubes of infauna organisms (cf. literature cited below).

Since most sediments are dependent upon a supply of organic material via sedimentation from the water column, major transformations of matter can be expected to occur at the sediment/water interface (cf. fine-scale investigations by Craven et al. 1986). This applies especially to pelagic sediments because they are characterized by a low supply of organic material undergoing strong seasonal variations. In these sediments the enzymatic hydrolysis of sedimented particulate organic material is the initial, rate-limiting step in organic carbon oxidation (Meyer-Reil \& Köster 1992).

During expeditions to the Norwegian-Greenland Sea extremely steep gradients of enzymatic degradation rates of organic material were measured at a number of sediments in the Jan Mayen fracture zone (Köster et al. 1991, Meyer-Reil \& Köster 1991). Microscale investigations revealed that in the uppermost 0 to $2.5 \mathrm{~mm}$ horizon hydrolytic activities were enhanced by more than 2 orders of magnitude over horizons only a few $\mathrm{mm}$ deeper. The extremely steep gradients in enzyme activities were closely related to mass abundances of epibenthic agglutinated foraminifera which densely colonized the sediment surface, extending their plasma nets into the water. Parallel to the steep gradients in enzymatic activities, pronounced microscale gradients in microbial numbers and especially biomass were observed. It may be speculated that in these sediments epibenthic foraminifera are the main decomposers of sedimented organic material. Microorganisms (especially bacteria) may benefit from the metabolism of the foraminifera rather than being the main decomposers.

The redox discontinuity layer (RDL) is characterized by a shift from oxic to anoxic conditions. Within this layer the microbial use of different electron acceptors and the oxidation of reduced compounds of anaerobic processes cause diverse microbial metabolic pathways. Micro-scale investigations of sediments from the North Sea south of the island of Helgoland revealed that during certain seasons of the year enzymatic decomposition rates of organic material were stimulated within or just below the RDL. Analyses by epifluorescence microscopy showed a parallel accumulation of microbial numbers and biomass. The stimulation of microbial activities was closely related to an accumulation of organic carbon and nitrogen. Through microbial metabolism the carbon to nitrogen $(\mathrm{C} / \mathrm{N})$ ratio decreased, caused by a preferential utilization of carbon over nitrogen. The diversity of microbial activities within the RDL can be inferred from concentration profiles of inorganic nutrients. The use of nitrate as electron acceptor caused a rapid decrease of nitrate; at the same time ammonium was released. Right below the RDL, phosphate was liberated caused by the reduction and mobilization of iron (Köster 1993).

A variety of investigations confirm that biogenic structures such as burrows and tubes of macrofauna organisms are zones of intensive microbial metabolism. This can be derived from total microbial numbers and biomass (e.g. Dobbs \& Guckert 1988, Köster 1993), distribution of different physiological groups of microbes (Reichardt 1986), enzymatic decomposition of organic matter (Köster 1993), dark fixation of carbon dioxide (Reichardt 1986), and microbial production 
(e.g. Alongi 1985, Reichardt 1988). The elevated levels of microbial activities can be attributed to the metabolism of the organisms (secretion of material) as well as to bioturbation activities (increase of solute transport by feeding, burrowing and irrigation). Micro-scale analyses of a sediment core inhabited by macrofauna organisms from the North Sea showed that microbial enzymatic activities were greatly stimulated in the vicinity of intact tubes of small polychaetes whereas empty tubes or debris of mussel shells revealed no elevated activity levels (Köster 1993).

The application of microelectrodes turned out to be a powerful tool for measurements of micro-scale variations of chemical parameters in the sediment environment. With this technique a spatial resolution in the range of some $10 \mu \mathrm{m}$ can be achieved that may relate to the direct sphere of influence of microbial assemblages. Using microelectrodes Meyers et al. (1987) demonstrated that vertical and horizontal micro-scale gradients of oxygen and sulfide were closely related to the tubes of meiofauna. Dodds (1989) measured micro-scale vertical profiles of oxygen to calculate photosynthesis in a cyanobacterial assemblage. Oxygen microelectrodes have been used to analyze the microstructure of diffusive boundary layers of mats and sediments (Gundersen \& Jørgensen 1990, Jørgensen \& Des Marais 1990). The authors could show that surface topography, flow velocity and benthic oxygen consumption greatly influenced diffusive boundary microgradients. Using a combined microsensor, the microzonation of oxygen and nitrous oxide was studied to derive denitrification rates in sediments (Christensen et al. 1989, Binnerup et al. 1992). From microprofiles of oxygen and nitrate in freshwater sediments, Jensen et al. (1993) determined depth profiles of nitrification and denitrification which were closely coupled. These are only a few examples of the application of microelectrodes to measure gradients of chemical parameters as an expression of microbial activities in natural communities.

Chemical parameters, however, are at best a reflection of microbial activities and cannot replace direct measures of microbial metabolism. Therefore from measurements of chemical parameters, various questions regarding responsible microbial activities remain open. Other than that natural microbial communities function, almost nothing is known about the distribution of different physiological groups of microorganisms and the arrangement of their individual activities or about the relation of activities to individual organisms within microbial biofilms.

The application of appropriate molecular biological techniques can be of great use to study the distribution of individual domains and subclasses of bacteria within biofilms. By using fluorescent oligonucleotide probes that bind to $16 \mathrm{~S}$ rRNA, Amann et al. (1992) could visualize specific sulfate-reducing bacterial populations within developing and established biofilms. Poulsen et al. (1993) measured significant differences in growth activities of single cells in young and established biofilms based on rRNA fluorescence in situ hybridization data. Ramsing et al. (1993) determined the distribution of sulfate-reducing bacteria in photosynthetic biofilms from the trickling filter of a sewage treatment plant with oligonucleotide probes. By combining the data with microelectrode measurements, the authors found that the distribution of sulfate reducers was negatively correlated with oxygen profiles, restricting the sulfate reducers largely to anoxic layers. Denitrifier probes were successfully applied to detect denitrifying bacteria from a bioreactor consortium (Smith \& Tiedje 1992).

Using fluorescence-labeled oligonucleotide probes complementary to regions of $16 \mathrm{~S}$ and 23S rRNA, Manz et al. (1993) found that more than $70 \%$ of the surfaceassociated microorganisms from drinking water biofilms determined by direct staining bound detectable amounts of rRNA-targeted probes. The authors observed that microcolonies consisted of mixed populations in early stages with fewer than 50 cells. From these observations it may be concluded that as soon as the initial stage of colonization, different physiological groups of cells settle in close spatial vicinity. However, it has to be investigated whether this occurs by chance or whether cells with related metabolism settle together.

High substrate turnover may be traced back to relatively low numbers of cells which are very active or to relatively high numbers of cells with relatively low individual activity. From the very few data reported in the literature, it can be derived that active cells in sediments account for about $5 \%$ of the total number of microbes (Chocair \& Albright 1981, Novitsky 1983). The low percentage reported in the literature is difficult to understand even if we consider the limitations of the autoradiographic method used (incorporation of individual radiolabelled low-molecular-weight organic substrates). To my knowledge, up to now the microautoradiography technique was not applied to follow micro-scale distributions of microbial activities in sedimentary biofilms.

Microautoradiography (Meyer-Reil 1978) as well as the quantification of respiring bacteria using vital redox dyes such as tetrazolium salts (Rodrigues et al. 1992) seem to be promising approaches for the microscale analyses of microbial activities. Following incubation with the corresponding substrates, sediment cores have to be sliced into thin sections and directly analyzed by microscopy after staining. Based upon the high optical resolution, activity may be directly related 
to individual microbial cells. Of special importance are experiments in which environmental conditions are changed (e.g. nutrient regime) to follow variations of distribution of organisms and cell-specific activities in comparison to untreated controls. It is of specific interest to relate shifts in microbial activities to micro-scale variations in chemical parameters determined by microelectrodes.

Almost nothing is known about the reaction of natural microbial assemblages to rapid changes in environmental conditions. Most of the sediments depend upon the supply of organic material via sedimentation from the water column. The organic material reaching the seafloor has a very patchy distribution. At locations where the material is enriched, a rapid consumption of oxygen caused by decomposition processes can be expected. As a consequence subsurface sediment horizons become anoxic because the consumption greatly exceeds the diffusion of oxygen. Aerobic bacteria are now faced with anaerobic conditions which restrict their metabolism. In contrast, under anaerobic conditions anaerobes start to metabolize. After exhaustion of nutrients oxygen may diffuse into the sediment, and the situation may be reversed. Anaerobes are inhibited by oxygen, and the metabolic processes are dominated by aerobes. The described scenario is only understandable if it is assumed that the microbial assemblages in sediments consist of omnipotent spectra of cells comprising 'all' different physiological groups of organisms. The specific ecological situation, however, determines which of the physiological groups will be active. This hypothesis may help to understand the low number of active cells determined in sediments.

\section{DISTRIBUTION AND AVAILABILITY OF ORGANIC CARBON}

As mentioned above, the organic material reaching the seafloor is heterogeneously distributed. Bioturbation by the benthic fauna may further contribute to the patchy distribution of dissolved and particulate nutrients. Besides the sedimented organic matter, dead and decaying organisms represent an additional unevenly distributed source of organic carbon. Even in nutrientpoor sediments, patches rich in organic matter may exist which will be overlooked if the corresponding spatial scale is not considered. Microorganisms in contact with nutrient particles are faced with relatively high concentrations of organic material. With increasing distance from the nutrient source, concentrations of material rapidly decrease. It can be assumed that the concentration gradient allows different physiological groups of microbes adapted to different nutrient regimes to metabolize and eventually to grow thus causing the nutrient gradient to diminish. Corresponding investigations, however, are lacking. The almost immediate response of microbial communities to nutrient enrichment again favours the hypothesis of the existence of microbial assemblages with omnipotent character (cf. above).

The organic detritus in sediments consists of a complex mixture of labile, semilabile, and resistant material. The small, labile fraction available for microorganisms is rapidly metabolized. With continued reworking by microbes, the organic matter becomes more and more resistant. Microbial decomposition and abiotic processes such as the condensation of reactive phenol and carbohydrate groups with amino acids yield precursors to complex nitrogenous humic geopolymers (Rice 1982). The process, however, is poorly understood. Because of its resistance against microbial attack, the material is very slowly metabolized. Investigations by Shimp \& Pfaender (1985) and Graf (1987) demonstrated that the availability of easily decomposable organic compounds stimulates the decomposition of complex organic matter. However, even resistant matter may ultimately be degraded, providing there is sufficient time for the bacteria to work on the material. The unexpectedly high microbial numbers and measurable activities found in deep sediment horizons are impressive examples of ongoing microbial modification and decomposition processes in sediments some $10000 \mathrm{yr}$ and more old (Parkes et al. 1990, Meyer-Reil 1993). Almost nothing is known about the physiological status of these bacteria. Microscopic images reveal small cocci which look like starvation forms (MeyerReil 1993). Taking into account the long time bacteria have to work on the material, considerable variations in quantity and quality of organic material can be expected, which have to be considered in interpretations of geochemical data. Traditionally, geologists and geochemists assumed that once the sedimented organic matter is buried below the bioturbated zone, the material will be no longer modified.

Very few attempts have been made to determine the available fraction of organic matter although this is one of the key parameters for the distribution of microbial activities in sediments (Nedwell \& Gray 1987). Chemical analyses of all potential substrate molecules is prevented by the variety of labile organic molecules often present in very low concentrations. Even if the chemical analyses were possible, the question of the bioavailability of the organic substrates remains open. Nedwell (1987) developed a microbiological technique using the growth of Pseudomonas aeruginosa as a reflection upon microbially available carbon in pore water or in aqueous extracts of sediments. The growth of the bacterial strain in response to available carbon was calibrated in a mineral salt medium containing 
known amounts of glucose. The available carbon in sediment extracts was calculated by comparison with the glucose standard expressed in terms of glucose carbon. As it could be shown, the pool of available carbon was extremely small, comprising about $1 \%$ at the surface and less than $0.2 \%$ of total organic carbon at depths greater than $10 \mathrm{~cm}$. A corresponding bioassay for the measurement of assimilable organic carbon in waters was proposed by LeChevallier et al. (1993). After killing the indigenous bacterial population, the water sample is inoculated with 1 or more test organisms. Following incubation the growth of the test organisms is monitored until the stationary-phase level is reached which is proportional to the amount of limiting nutrients in the water.

There are a number of limitations to the techniques described. In natural sediments the pool of available carbon is metabolized by a succession of different physiological groups of microbes including aerobic and anaerobic organisms until complete mineralization has occurred. The spectrum of substrates metabolized by a single bacterium may be more restricted than the spectrum metabolized by natural bacterial assemblages. Furthermore the growth limiting nutrient for the test bacterium may not be carbon. Even in the presence of available carbon, other components such as toxins may restrict the growth of the test bacterium. Thus the techniques described characterize at the best the growth potential of the sample. However, since microbially available carbon is measured, a bioassay is superior over chemical analyses because of its sensitivity. Therefore it is not surprising that scientists have become more and more aware of the advantages of sensitive bioassays. In this connection the highly sensitive denitrification assay for the detection of nitrate and nitrite in rhizosphere soil developed by Binnerup \& Sørensen (1992) needs special attention. The application of bioassays to the environment at the corresponding (microbially) spatial scale is the approach that needs to be adopted in order to address some of the urgent questions in ecology that cannot be solved using traditional approaches.

\section{CONCLUSIONS}

Until recently microbial ecologists tended to deny natural heterogeneity and variability of microbial assemblages in sediments. Sediments were treated as homogeneous systems and analyzed according to spatial scales measured in arbitrarily chosen depth intervals. Heterogeneity was regarded as deviation from normality and as an unfortunate fault of nature. With this traditional approach, the opportunity is missed to understand and to accept heterogeneity as the driving force for microbial activities, and to design methods that are suited for analyses at the corresponding spatial scale. The application of microelectrodes turned out to be a powerful tool to measure micro-scale distributions of chemical parameters in sediments. However, chemical parameters are at best a reflection of microbial activities and cannot replace direct microscale measures of microbial metabolism. For this purpose the determination of substrate uptake or respiration is the first step in the right direction. Based upon the microscopic analyses, activity may be related to individual cells. Experiments have to be designed in which micro-scale variations of microbial distribution and activities are related to microgradients of chemical parameters.

Traditionally, microorganisms have been regarded as simply reacting to environmental parameters. Much more attention has to be paid to the fact that microorganisms in sedimentary biofilms condition specific features of their environment by the secretion of extracellular polysaccharides (EPS). Variations in environmental parameters might affect microbial assemblages much less than was previously thought. Again, microscale measurements in the biofilms rather than in the bulk sediment are required. Variations in chemical parameters have to be interpreted primarily as the result of microbial activities. With regard to chemical parameters, concentrations are of limited value as long as we cannot answer the question of availability. If we want to learn more about how natural microbial assemblages function, we have to modify our strategies.

Acknowledgements. A number of colleagues and students contributed through discussions to the content of this article. Their contribution to this fascinating field of microbial ecology is greatly acknowledged. This article is based on research activities financed by the Deutsche Forschungsgemeinschaft during past and ongoing interdisciplinary programmes (Sonderforschungsbereich 313, Christian-Albrechts-Universität zu Kiel, publication no. 225; special research programme 'Struktur- und Funktionsanalyse natürlicher mikrobieller Lebensgemeinschaften', Me 509/5-1).

\section{LITERATURE CITED}

Alongi, D. M. (1985). Microbes, meiofauna, and bacterial productivity on tubes constructed by the polychaete Capitella capitata. Mar. Ecol. Prog. Ser. 23: 207-208

Amann, R. I., Stromley, J., Devereux, R., Key, R., Stahl, D. A. (1992). Molecular and microscopic identification of sulfate-reducing bacteria in multispecies biofilms. Appl. environ. Microbiol. 58: 614-623

Bernhard, J. M., Bowser, S. S. (1992). Bacterial biofilms as a trophic resource for certain benthic foraminifera. Mar. Ecol. Prog. Ser. 83: 263-272

Binnerup, S. J., Jensen, K., Revsbech, N. P., Jensen, M. H. Sørensen, J. (1992). Denitrification, dissimilatory reduction of nitrate to ammonium, and nitrification in a bioturbated estuarine sediment as measured with ${ }^{15} \mathrm{~N}$ and 
microsensor techniques. Appl. environ. Microbiol. 58: 303-313

Binnerup, S. J., Sørensen, J. (1992). Nitrate and nitrite microgradients in barley rhizosphere as detected by highly sensitive denitrification bioassay. Appl. environ. Microbiol. 58: $2375-2380$

Boyle, C. D., Reade, A. E. (1983). Characterization of two extracellular polysaccharides from marine bacteria. Appl. environ. Microbiol. 46: 392-399

Cammen, L. M. (1980). The significance of microbial carbon in the nutrition of the deposit feeding polychaete Nereis succinea. Mar. Biol. 61: 9-20

Characklis, W. G., Marshall, K. C. (1990). Biofilms. John Wiley \& Sons, Inc., New York

Characklis, W. G., Wilderer, P. A. (1989). Structure and function of biofilms. John Wiley \& Sons, Chichester

Chocair, J. A., Albright, L. A. (1981). Heterotrophic activities of bacterioplankton and bacteriobenthos. Can. J. Microbiol. 27: 259-266

Christensen, P. B., Nielsen, L. P., Revsbech, N. P., Sørensen, J. (1989). Microzonation of denitrification activity in stream sediments as studied with a combined oxygen and nitrous oxide microsensor. Appl. environ. Microbiol. 55: $1234-1241$

Craven, D. B., Jahnke, R. A., Carlucci, A. F. (1986). Fine-scale distribution of microbial biomass and activity in California Borderland sediments. Deep Sea Res. 33: 379-390

Dale, N. G. (1974). Bacteria in intertidal sediments: factors related to their distribution. Limnol. Oceanogr. 19: $509-518$

Decho, A. W. (1990). Microbial exopolymer secretions in ocean environments: their role(s) in food webs and marine processes. Oceanogr. mar. Biol. A. Rev. 28; 73-153

DeFlaun, M. F., Mayer, L. M. (1983). Relationships between bacteria and grain surfaces in intertidal sediments. Limnol. Oceanogr. 28: 873-881

Deming, J. W., Baross, J. A. (1993). The early diagenesis of organic matter: bacterial activity. In: Engel, M. H., Macko, S. A. (eds.) Organic geochemistry. Plenum Press, New York, p. 119-144

Dobbs, F. C., Guckert, J. B. (1988). Callianassa trilobata (Crustacea: Thalassinidae) influences abundance of meiofauna and biomass, composition, and physiological state of microbial communities within its burrow. Mar. Ecol. Prog. Ser. 45: 69-79

Dodds, W. K. (1989). Microscale vertical profiles of $\mathrm{N}_{2}$ fixation, photosynthesis, $\mathrm{O}_{2}$, chlorophyll $a$, and light in a cyanobacterial assemblage. Appl. environ. Microbiol. 55: 882-886

Ehrlich, H. L. (1990). Geomicrobiology. Marcel Dekker, Inc. New York

Ferris, F. G., Schultze, S., Witten, T. C., Fyfe, W. S., Beveridge, T. J. (1989). Metal interactions with microbial biofilms in acidic and neutral $\mathrm{pH}$ environments. Appl. environ. Microbiol. 55: 1249-1257

Flemming, H.-C., Geesey, G. G. (1991). Biofouling and biocorrosion in industrial water systems. Springer-Verlag, Berlin

Fletcher, M., Marshall, K. C. (1982). Are solid surfaces of ecological significance to aquatic bacteria? In: Marshall, K. C. (ed.) Advances in microbial ecology, Vol, 6. Plenum Press, New York, p. 199-236

Geesey, G. G., Jang, L., Jolley, J. G., Hankins, M. R., Iwaoka, T., Griffiths, P. R. (1988). Binding of metal ions by extracellular polymers of biofilm bacteria. Water Sci. Technol. 20: $161-165$

Graf, G. (1987). Benthic energy flow during a simulated autumn bloom sedimentation. Mar. Ecol. Prog. Ser. 39. 23-29

Gundersen, J. K., Jørgensen, B. B. (1990). Microstructure of diffusive boundary layers and the oxygen uptake of the sea floor. Nature 345: 604-607

Harvey, M., Forsberg, C. W., Beveridge, T. J., Pos, J., Ogilvie, J. R. (1984). Methanogenic activity and structural characteristics of microbial biofilm on a needle-punched polyester support. Appl. environ. Microbiol. 48: 633-638

Jensen, K., Revsbech, N. P., Nielsen, L. P. (1993). Microscale distribution of nitrification activity in sediment determined with a shielded microsensor for nitrate. Appl. environ. Microbiol. 59: 3287-3296

Jørgensen, B. B., Des Marais, D. J. (1990). The diffusive boundary layer of sediments: oxygen microgradients over a microbial mat. Limnol. Oceanogr. 35: 1343-1355

Konhauser, K. O., Schultze-Lam, S., Ferris, F. G., Fyfe, W. S., Longstaffe, F. J., Beveridge, T. J. (1994). Mineral precipitation by epilithic biofilms in the Speed River, Ontario, Canada. Appl. environ. Microbiol. 60: 549-553

Köster, M. (1993). Mikrobielle Aktivitäten an Grenzflächen. In: Meyer-Reil, L.-A., Köster, M. (eds.) Mikrobiologie des Meeresbodens. Gustav Fischer Verlag, Jena, p. 82-120

Köster, M., Jensen, P., Meyer-Reil, L.-A. (1991). Hydrolytic activities of organisms and biogenic structures in deep-sea sediments. In: Chróst, R. J. (ed.) Microbial enzymes in aquatic environments. Springer-Verlag, New York, p. 298-310

LeChevallier, M. W., Shaw, N. E., Kaplan, L. A., Bott, T. L. (1993). Development of a rapid assimilable organic carbon method for water. Appl. environ. Microbiol. 59: 1526-1531

Manz, W., Szewzyk, U., Ericsson, P., Amann, R., Schleifer, K.-H., Stenström, T.-A. (1993), In situ identification of bacteria in drinking water and adjoining biofilms by hybridization with $16 \mathrm{~S}$ and $23 \mathrm{~S}$ rRNA-directed fluorescent oligonucleotide probes. Appl. environ. Microbiol. 59: 2293-2298

Mayer, L. M. (1989). The nature and determination of non-living sedimentary organic matter as a food source for deposit feeders. In: Bowman, M. J., Barber, R. T., Mooers, C. N. K., Raven, J. A. (eds.) Lecture notes on coastal and estuarine studies, Vol. 31, Ecology of marine deposit feeders. Springer-Verlag, New York, p. 98-113

Meadows, P. S., Anderson, J. G. (1966). Microorganisms attached to marine and freshwater grains. Nature 198: $610-611$

Meyer-Reil, L.-A. (1978). Autoradiography and epifluorescence microscopy combined for the determination of number and spectrum of actively metabolizing bacteria in natural waters. Appl. environ. Microbiol. 36: 506-512

Meyer-Reil, L.-A. (1990). Microorganisms in marine sediments: considerations concerning activity measurements. Arch. Hydrobiol. (Beih. Ergebn. Limnol.) 34: 1-6

Meyer-Reil, L.-A. (1991). Ecological aspects of enzymatic activity in marine sediments. In: Chróst, R. J. (ed.) Microbial enzymes in aquatic environments. Springer-Verlag, Berlin, p. 298-310

Meyer-Reil, L.-A. (1993). Mikrobielle Besiedlung und Produktion. In: Meyer-Reil, L.-A., Köster, M. (eds.) Mikrobiologie des Meeresbodens. Gustav Fischer Verlag, Jena, p. $38-81$

Meyer-Reil, L.-A., Köster, M. (1991). Fine-scale distribution of hydrolytic activity associated with foraminiferans and bacteria in sediments of the Norwegian-Greenland Sea. Kieler Meeresforsch., Sonderh. 8: 127-138

Meyer-Reil, L.-A., Köster, M. (1992). Microbial life in pelagic sediments: the impact of environmental parameters on 
enzymatic degradation of organic material. Mar. Ecol. Prog. Ser. 81: 65-72

Meyers, M. B., Fossing, H., Powell, E. N. (1987). Microdistribution of interstitial meiofauna, oxygen and sulfide gradients, and the tubes of macro-infauna. Mar. Ecol. Prog. Ser. 35: 223-241

Moriarty, D. J. W., Hayward, A. C. (1982). Ultrastructure of bacteria and the proportion of Gram-negative bacteria in marine sediments. Microb. Ecol. 8: 1-14

Morrison, S. J., King, J. D., Bobbie, R. J., Bechthold, R. E., White, D. C. (1977). Evidence for microfloral succession on allochthonous plant litter in Apalachicola Bay, Florida, USA. Mar. Biol. 41: 229-240

Nedwell, D. B. (1987). Distribution and pool sizes of microbially available carbon in sediment measured by a microbiological assay. FEMS Microbiol. Ecol. 45: 47-52

Nedwell, D. B., Gray, T. R. G. (1987). Soils and sediments as matrices for microbial growth. In: Fletcher, M., Gray, T. R. G., Jones, J. G. (eds.) Ecology of microbial communities. Cambridge University Press, Cambridge, p. 21-54

Novitsky, J. A. (1983). Heterotrophic activity throughout a vertical profile of seawater and sediment in Halifax Harbor, Canada. Appl, environ. Microbiol. 45: 1753-1760

Parkes, R. J., Cragg, B. A., Fry, J. C., Herbert, R. A., Wimpenny, J. W. T. (1990). Bacterial biomass and activity in deep sediment layers from the Peru margin. Phil. Trans. R. Soc. A 331: 139-153

Poulsen, L. K., Ballard, G., Stahl, D. A. (1993). Use of rRNA fluorescence in situ hybridization for measuring the activity of single cells in young and established biofilms. Appl. environ. Microbiol. 59: 1354-1360

Ramsing, N. B., Kühl, M., Jørgensen, B. B. (1993). Distribution of sulfate-reducing bacteria, $\mathrm{O}_{2}$, and $\mathrm{H}_{2} \mathrm{~S}$ in photosynthetic biofilms determined by oligonucleotide probes and microelectrodes. Appl. environ. Microbiol. 59: 3840-3849

Reichardt, W. (1986). Polychaete tube walls as zonated microhabitats for marine bacteria. IFREMER, Actes de Colloques 3: 415-425

Reichardt, W. (1988). Impact of bioturbation by Arenicola

This review was submitted to the editor marina on microbiological parameters in intertidal sediments. Mar. Ecol. Prog. Ser, 44: 149-158

Rice, D. L. (1982). The detritus nitrogen problem: new observations and perspectives from organic geochemistry, Mar. Ecol. Prog. Ser. 9: 153-162

Robinson, R. W., Akin, D. E., Nordstedt, R. A., Thomas, M. V. Aldrich, H. C. (1984). Light and electron microscopic examinations of methane-producing biofilms from anaerobic fixed-bed reactors. Appl. environ. Microbiol. 48: 127-136

Rodrigues, G. G., Phipps, D., Ishiguro, K., Ridgway, H. F. (1992). Use of a fluorescent redox probe for direct visualization of actively respiring bacteria. Appl. environ. Microbiol. 58: 1801-1808

Rublee, P., Dornseif, B. E. (1978). Direct counts of bacteria in the sediments of a North Carolina salt marsh. Estuaries 1: 188-191

Shaw, J. C., Bramhill, B., Wardlaw, N. C., Costerton, J. W. (1985). Bacterial biofouling in a model core system. Appl. environ. Microbiol. 49: 693-701

Shimp, R., Pfaender, F. K. (1985). Influence of naturally occurring humic acids on biodegradation of monosubstituted phenols by aquatic bacteria. Appl. environ. Microbiol. 49: 402-407

Smith, G. B., Tiedje, J. M. (1992). Isolation and characterization of a nitrite reductase gene and its use as a probe for denitrifying bacteria. Appl. environ. Microbiol. 58: 376-384

Vandevivere, P., Kirchman, D. L. (1993). Attachment stimulates exopolysaccharide synthesis by a bacterium. Appl. environ. Microbiol. 59: 3280-3286

Wahl, M. (1989). Marine epibiosis. I. Fouling and antifouling: some basic aspects. Mar. Ecol. Prog. Ser. 58: 175-189

Watling, L. (1988). Small-scale features of marine sediments and their importance to the study of deposit-feeding. Mar. Ecol. Prog. Ser. 47: 135-144

Weise, W., Rheinheimer, G. (1978). Scanning electron microscopy and epifluorescence investigations of bacterial colonization of marine sand sediments. Microb. Ecol. 4: $175-188$

Manuscript first received: April 18, 1994

Revised version accepted: June 8, 1994 